\title{
ANTIHIPERGLIKEMIK EKSTRAK TUMBUHAN SURUHAN (Peperomia pellucida [L.] Kunth) TERHADAP TIKUS WISTAR (Rattus norvegicus L.) YANG DIINDUKSI SUKROSA
}

\author{
Nafila Salma ${ }^{1)}$, Jessy Paendong ${ }^{1)}$, Lidya I. Momuat ${ }^{1)}$, Sariyana Togubu ${ }^{1)}$ \\ ${ }^{1)}$ Program Studi Kimia FMIPA Universitas Sam Ratulangi \\ J1. Kampus Unsrat Manado 95115 \\ Navila.salma@gmail.com, paendongjessy@gmail.com, 1momuat@yahoo.com, \\ sariyana.togubu@gmail.com
}

\begin{abstract}
ABSTRAK
Telah dilakukan penelitian untuk menentukan dosis optimum dari ekstrak tumbuhan suruhan (Peperomia pellucida [L.] Kunth) sebagai antihiperglikemik tikus wistar yang diinduksi sukrosa. Penelitian ini menggunakan metode uji toleransi glukosa. Digunakan tikus putih jantan wistar berjumlah 20 ekor tikus yang dibagi dalam 5 kelompok perlakuan yaitu kelompok perlakuan kontrol negatif (K-) diberi CMC 0,5\%, kelompok perlakuan kontrol positif $(\mathrm{K}+)$ diberi Glibenklamid dosis $0,45 \mathrm{mg} / \mathrm{kgBB}$, kelompok perlakuan ekstrak tumbuhan suruhan dosis 20; 40; $80 \mathrm{mg} / \mathrm{kgBB}$. Data diperoleh dari pemeriksaan kadar gula darah puasa (basal), 30 menit setelah diindukasi sukrosa dan pada menit ke 30, 60, dan 120 setelah diinduksi sediaan per oral. Data diolah dengan uji ANOVA dan Ducan untuk membandingkan antara kelompok kontrol negatif, ekstrak dan kontrol positif. Data hasil pengujian kadar glukosa darah dengan dosis 20;40;80 $\mathrm{mg} / \mathrm{kgBB}$ memberikan penurunan kadar glukosa darah. Pemberian ekstrak tumbuhan suruhan dengan dosis $40 \mathrm{mg} / \mathrm{kgBB}$ pada menit ke-120 memberikan hasil yang signifikan dan bebeda nyata dibandingkan kelompok kontrol negatif (CMC 0,5\%) dan tidak berbeda nyata dengan glibenklamid dosis $0,45 \mathrm{mg} / \mathrm{kgBB}$. Kesimpulannya pemberian ekstrak tumbuhan suruhan dosis 40 $\mathrm{mg} / \mathrm{kgBB}$ pada menit ke 120 memberikan penurunan kadar glukosa darah yang efektif dan berbeda nyata (signifikan) dibandingkan pemberian ekstrak tumbuhan suruhan dosis 20 dan 80 $\mathrm{mg} / \mathrm{kgBB}$.
\end{abstract}

Kata Kunci : Peperomia pellucida [L.] Kunth, Tumbuhan Suruhan, Kadar Glukosa Darah, Sukrosa.

\section{ANTIHYPERGLYCEMIC FROM SURUHAN PLANT (Peperomia pellucida [L.] Kunth) EXTRACT AGAINST WISTAR RATS (Rattus norvegicus L.) WITH INCLUDED BY SOURCE}

\begin{abstract}
The purpose of this research is to determine optimum dose of Suruhan (Peperomia pellucida [L.] Kunth) extract as Antihyperglycemic agent against Wistar Rats with Induced by Sucrose. This research using glucose tolerance test methods. Used 20 male Wistar rats were divided into 5 groups, they are the negative control treatment group (K-) were given $0.5 \% \mathrm{CMC}$, the positive control groups $(\mathrm{K}+)$ given $0,45 \mathrm{mg} / \mathrm{kgBB}$ Glibenklamid, and Suruhan extract treatment group of $20 ; 40 ; 80 \mathrm{mg} / \mathrm{kgBB}$ dose. Data obtained from the examination offasting blood sugar (basal) content, 30 minutes after induced bysucroseandat minute of 30, 60, and120 after-induced oraldosage.The data were processed by ANAVA and LSD testtocompare betweenthe negativecontrol group, the extractandpositive control. Dataresults of testing blood sugar levels with doses of $20,40,80 \mathrm{mg} / \mathrm{kgBB}$ gavea decreasein blood glucose levels were significant and significantly different than the negative control group (CMC $0.5 \%$ ) and did not give a clear difference with $0.45 \mathrm{mg} / \mathrm{kgBB}$ dose of Glibenclamide. Agents of plant extract at a dose of 40 $\mathrm{mg} / \mathrm{kgBB}$ body weight gives better results to the decline in blood glucose levels compared with doses of 20 and $80 \mathrm{mg} / \mathrm{kgBB}$. In conclusion, Suruhan plant extract has an effect on blood glucose levels decreased against white male Wistar rats were induced sucrose.
\end{abstract}

Keywords : Peperomia pellucida [L.] Kunth, Suruhan Plant, Blood Glucose Levels, Sucrose. 


\section{PENDAHULUAN}

Penderita diabetes melitus terus meningkat seiring dengan meningkatnya tingkat kemakmuran, gaya hidup, dan pola makan yang tidak sehat. Setiap orang dapat mengidap penyakit diabetes melitus baik tua maupun muda. Menurut World Health Organization (WHO) tahun 2003 terdapat lebih dari 200 juta orang penderita diabetes melitus di dunia. Negara berkembang seperti Indonesia menempati urutan ke-4 jumlah penderita diabetes melitus di dunia setelah India, Cina dan Amerika Serikat (Soegondo et al., 2009).

Diabetes melitus atau dikenal dengan penyakit kencing manis merupakan penyakit kelainan metabolik yang ditandai dengan kenaikan kadar gula darah (Mun'im et al., 2011). Pengobatan diabetes melitus adalah pengobatan menahun dan seumur hidup. Pengobatan diabetes melitus seperti penggunaan insulin dan obat antihiperglikemik oral harganya relatif lebih mahal, penggunaannya dalam jangka waktu lama dan dapat menimbulkan efek samping yang tidak diinginkan. Oleh karena itu, perlu dicari obat yang efektif dengan harga yang murah dan efek samping yang relatif rendah (Hussain and Marouf, 2013).

Salah satu spesies tumbuhan yang dimanfaatkan dalam pengobatan tradisional adalah tumbuhan suruhan (Peperomia pellucida [L.] Kunth). Menurut Masyarakat Medis Manila Peperomia pellucida [L.] Kunth digunakan untuk mengobati pusing, sakit kepala, demam dan hasil perasan daunnya dapat digunakan untuk pengobatan sakit perut, meredakan nyeri, rematik, tetapi dapat menyebabkan depresi. Tumbuhan ini juga dilaporkan memiliki aktifitas antiinflamasi (Wijaya dan Monica, 2004), antibakteri, antikanker, obat demam dan setelah diteliti ternyata dilaporkan memiliki aktifitas antipiretik (Khan et al., 2008), serta digunakan sebagai obat antihipertensi (Nwokocha et al., 2012).

Kandungan senyawa yang ada dalam Peperomia pellucida [L.] Kunth adalah alkaloid. Peperomia pelusida juga mengandung beberapa minyak esensial, terutama dillapiole, $\beta$-caryophyllene dan carotol yang memiliki aktivitas larvisida tinggi (Xu et al., 2005). Senyawa lainnya adalah flavonoid seperti acacetin, apigenin, isovitexin dan pellucidatin, pitosterol, yaitu, campesterol, stigmasterol, dan arylproppanoids. Glikosida jantung, tanin dan antrakuinon juga telah diisolasi dari tanaman (Nwokocha et al., 2012).

Telah dilaporkan oleh Kusumawarni (2012), tumbuhan suruhan memiliki aktivitas antihiperglikemik. Tetapi sejauh ini informasi mengenai tumbuhan suruhan dengan variasi dosis sebagai antihiperglikemik masih belum ditemukan, untuk itu penelitian ini dilakukan.

\section{METODOLOGI PENELITIAN}

\subsection{Alat dan Bahan Penelitian}

Alat-alat yang digunakanyaitualatalatgelaspyrex, timbangananalitik, oven, rotary evaporator, ayakan 65 mesh, nasogastric tube (NGT) no. 3,5 dan disposible syringe $3 \mathrm{~mL}$, alat ukur gula darah yaituGlucoDr dan GlucoDrStrip (Blood Glucose Test Meter).

Bahan-bahan yang digunakan dalam penelitian yaitu tumbuhan suruhan, darah tikus putih jantan wistar (Rattus norvegicus L.) yang diambil dari bagian ekor, etanol,Carboxy Methyl Cellulose (CMC), akuades, sukrosa (gula pasir), glibenkamid dan pakan ternak.

\subsection{Metode Penelitian}

\subsubsection{Preparasi Sampel}

Tumbuhan suruhan (Peperomia pellucida [L.] Kunth) segar 7600 g dikeringkan dengan cara diangin-anginkan dan dikeringkan dengan oven pada suhu 50 ${ }^{\circ} \mathrm{C}$ sampai menjadi simplisia.

\subsubsection{Pembuatan Ekstrak}

Penelitian ini menggunakan ekstrak etanol campuran dari akar, batang dan daun suruhan. Sebelum dieksrtaksi serbuk tumbuhan suruhan diuji kadar air. Metode penentuan kadar air mengacu pada metode Helrich (1995). Pada penelitian ini tumbuhan suruhan diekstraksi dengan etanol 95\%. Pembuatan ekstrak tumbuhan suruhan dilakukan dengan metode maserasi, yaitu serbuk tumbuhan suruhan ditimbang sebanyak $350 \mathrm{~g}$ lalu diekstraksi dengan menggunakan 2,5 L etanol dengan cara maserasi selama 5 hari. Ekstrak kemudian disaring dengan menggunakan kertas saring (filtrat 1) dan sisanya diekstrak kembali 
selama 2 hari menggunakan $1 \mathrm{~L}$ etanol lalu disaring (filtrat 2). Selanjutnya filtrat 1 dan 2 digabungkan, diuapkan dengan rotary evaporator pada suhu $70{ }^{0} \mathrm{C}$ sampai volumenya menjadi $1 / 4$ dari volume awal dan dilanjutkan dengan pengeringan di oven pada suhu $40{ }^{\circ} \mathrm{C}$ sampai menjadi ekstrak kental.

\subsubsection{Pembuatan Larutan Sukrosa}

Menurut Kanon (2012), Dosis sukrosa yang digunakan untuk tikus adalah $5625 \mathrm{mg} / \mathrm{kgBB}$. Banyaknya sukrosa yang akan digunakan, dihitung berdasarkan berat badan dari masing-masing tikus, kemudian dilarutkan dalam akuades sebanyak $2,5 \mathrm{~mL}$ dan diinduksi pada masing-masing tikus.

\subsubsection{Pembuatan Larutan CMC 0,5\%}

Sebanyak 0,5 g CMC ditaburkan dalam gelas piala yang berisi $\pm 30 \mathrm{~mL}$ akuades yang telah dipanaskan. Didiamkan selama 15 menit hingga diperoleh massa yang transparan, lalu dicampur sampai homogen. Larutan CMC dipindahkan ke labu ukur $100 \mathrm{~mL}$ dan dicukupkan volumenya dengan akuades hingga tanda tera.

\subsection{5 .Pembuatan Larutan Glibenklamid Dosis 0,45 mg/kgBB}

Dosis Glibenklamid pada manusia dewasa adalah $5 \mathrm{mg}$, jika dikonversikan pada tikus dengan berat $200 \mathrm{~g}$ adalah 0,09 $\mathrm{mg} / \mathrm{kgBB}$, maka dosis Glibenklamid untuk tikus adalah $0,45 \mathrm{mg} / \mathrm{kgBB}$ dalam $18 \mathrm{mg}$ serbuk Glibenklamid. Banyaknya serbuk Glibenklamid yang akan digunakan, dihitung berdasarkan berat badan dari masing-masing tikus, kemudian dilarutkan dalam CMC $0,5 \%$ sebanyak $1 \mathrm{~mL}$ dan diinduksi pada masing-masing tikus.

\subsubsection{Pembuatan Larutan Ekstrak Tumbuhan Suruhan Dosis 20; 40; 80 mg/kgBB}

Ekstrak tumbuhan suruhan diberikan secara oral pada tikus wistar. Ekstrak hanya diberikan 3 kali yaitu segera setelah pengukuran kadar glikosa darah tikus pada menit ke-30;60;120 setelah diinduksi dengan larutan sukrosa.

Dosis pemakaian tumbuhan suruhan segar pada manusia dewasa $(50 \mathrm{~kg})$ adalah 100 g. Dengan faktor konversi dosis dari manusia $(70 \mathrm{~kg}) \mathrm{ke}$ tikus $(200 \mathrm{~g})$ adalah 0,018, maka dosis yang akan diberikan kepada tikus adalah $12,6 \mathrm{~g} / \mathrm{kgBB}$ untuk berat basah tumbuhan suruhan. Dalam penelitian ini akan dibuat variasi dosis yaitu $50 \mathrm{~g}, 100$ $\mathrm{g}$ dan $200 \mathrm{~g}$ berat basah tumbuhan suruhan untuk manusia dan telah dikonversikan menjadi 6,$3 ; 12,6 ; 25,2 \mathrm{~g} / \mathrm{kgBB}$ berat basah tumbuhan suruhan untuk tikus. Maka dosis ekstrak yang akan diberikan pada tikus adalah $20 ; 40 ; 80 \mathrm{mg} / \mathrm{KgBB}$ yang setara dengan dosis berat basah tumbuhan suruhan untuk tikus.

Banyaknya ekstrak tumbuhan suruhan yang akan digunakan, dihitung berdasarkan berat badan dari masing-masing tikus, kemudian dilarutkan dalam CMC $0,5 \%$ sebanyak $1 \mathrm{~mL}$ dan diinduksi pada masing-masing tikus.

\subsubsection{Pengujian Efek Ekstrak Tumbuhan Suruhan terhadap Kadar Glukosa Darah}

Sebelum percobaan dilakukan, tikus dipuasakan (tidak diberi makan, hanya diberi minum) selama 12 jam, lalu ditimbang berat badan tikus. Masing-masing tikus diukur kadar glukosa darah puasa (basal) dengan cara digunting bagian ujung ekor tikus. Darah yang keluar disentuhkan pada test strip yang telah terpasang pada alat glucometer dan dibiarkan alat mengukur kadar glukosa darah secara otomatis. Angka yang tampil pada layar dicatat sebagai kadar glukosa darah (mg/dL).

Diinduksi sukrosa sebesar 5625 $\mathrm{mg} / \mathrm{kgBB}$. Setelah 30 menit, tikus diperiksa kadar glukosa darah sesudah diinduksi sukrosa. Selanjutnya, tikus diberi sediaan per oral, untuk kelompok perlakuan kontrol negatif (K-) hanya diberi CMC 0,5\%, untuk kelompok perlakuan kontrol positif $(\mathrm{K}+)$ diberi glibenklamid dengan dosis 0,45 $\mathrm{mg} / \mathrm{KgBB}$, kelompok perlakuan ekstrak tumbuhan suruhan (TS) diberi ekstrak tumbuhan suruhan dengan dosis 20 $\mathrm{mg} / \mathrm{kgBB}\left(\mathrm{TS}_{1}\right), 40 \mathrm{mg} / \mathrm{kgBB}\left(\mathrm{TS}_{2}\right)$ dan 80 $\mathrm{mg} / \mathrm{kgBB}\left(\mathrm{TS}_{3}\right)$. Kadar glukosa darah tikus diperiksa pada menit ke-30, 60, dan 120 menit setelah diinduksi sediaan per oral. Semua sampel darah diambil dari vena ekor tikus dan kadar glukosa darah diukur dengan glukometer GlucoDr dan GlucoDr Strip (Blood Glucose Test Meter).

\subsubsection{Analisis Data}

Data yang diperoleh dianalisis dengan menggunakan program statistika SAS. Beda nyata antar perlakuan diuji dengan ANAVA yang kemudian dilanjutkan dengan uji Duncan. 


\section{HASIL DAN PEMBAHASAN}

\subsection{Ekstraksi Sampel}

Ekstrak kental yang didapat sebanyak 24,05 g dan rendemen ekstrak dihitung sebesar $6,87 \%$. Metode ekstraksi yang digunakan pada penelitian ini adalah maserasi. Maserasi dipilih karena memiliki keunggulan, yakni pengerjaan yang cepat dan cara pengerjaan dan peralatan yang digunakan sederhana, relatif mudah dan murah (Samuelsson, 1999).

\subsection{Pengujian Efek Ekstrak Tumbuhan Suruhan terhadap Kadar Glukosa Darah Tikus}

Pengukuran rata-rata kadar glukosa darah dilakukan sebanyak 5 kali yaitu kadar glukosa darah sebelum (basal) dan sesudah diinduksi sukrosa, serta kadar glukosa darah pada menit ke-30, 60, dan 120 setelah induksi. Hasil pengukuran rata-rata kadar glukosa darah dapat dilihat pada Tabel 1 .

Tabel 1.Hasil Pengukuran Kadar Glukosa Darah Tikus (mg/dL)

\begin{tabular}{|c|c|c|c|c|c|}
\hline \multirow{3}{*}{$\begin{array}{l}\text { Kelompok } \\
\text { Perlakuan }\end{array}$} & \multicolumn{5}{|c|}{ Kadar Glukosa Darah (mg/dL) } \\
\hline & \multirow[t]{2}{*}{ Basal } & \multirow{2}{*}{$\begin{array}{l}\text { Induksi } \\
\text { Sukrosa }\end{array}$} & \multicolumn{3}{|c|}{ Waktu Setelah Induksi sukrosa } \\
\hline & & & 30 menit & 60 menit & 120 menit \\
\hline $\mathrm{K}(-)$ & \multirow{5}{*}{78,11} & \multirow{5}{*}{189,98} & $242,67^{b}$ & $252,00^{\mathrm{a}}$ & $209,67^{\mathrm{c}}$ \\
\hline $\mathrm{K}(+)$ & & & $132,33^{\mathrm{e}}$ & $108,67^{\mathrm{g}}$ & $77,33^{i}$ \\
\hline $\mathrm{TS}_{1}$ & & & $145,75^{\mathrm{d}}$ & $124,5^{\mathrm{f}}$ & $85,5^{\mathrm{h}}$ \\
\hline $\mathrm{TS}_{2}$ & & & $145,25^{\mathrm{d}}$ & $122,75^{\mathrm{f}}$ & $79,5^{1}$ \\
\hline $\mathrm{TS}_{3}$ & & & $150,75^{\mathrm{d}}$ & $134,00^{\mathrm{e}}$ & $104,00^{\mathrm{g}}$ \\
\hline
\end{tabular}

Catatan :Huruf yang sama dibelakang angka menunjukkan tidak ada beda nyata

Keterangan:
(K-)
: Kontrol negatif diberi CMC 0,5\% (Carboxy Methyl Cellulose 0,5\%)
$(\mathrm{K}+)$
: Kontrol positif diberi Glibenklamid dosis $0,45 \mathrm{mg} / \mathrm{kgBB}$
$\mathrm{TS}_{1}$
: Kontrol Perlakuan Ekstrak Tumbuhan Suruhan dengan dosis $20 \mathrm{mg} / \mathrm{kgBB}$
$\mathrm{TS}_{2}$
: Kontrol Perlakuan Ekstrak Tumbuhan Suruhan dengan dosis $40 \mathrm{mg} / \mathrm{kgBB}$
$\mathrm{TS}_{3}$
: Kontrol Perlakuan Ekstrak Tumbuhan Suruhan dengan dosis 80 mg/kgBB

Hasil pengukuran kadar glukosa darah dapat dilihat pada Tabel 1. Kadar glukosa darah tikus sebelum diberi sukrosa (basal) sebesar $78,11 \mathrm{mg} / \mathrm{dL}$. Nilai ini merupakan kadar glukosa darah normal bagi tikus, dan mendukung data yang dikemukakan oleh Taguchi (1985) bahwa kadar glukosa darah normal tikus putih dengan jenis kelamin jantan adalah $<105$ $\mathrm{mg} / \mathrm{dL}$.

Pada Tabel 1, kadar glukosa darah tikus setelah 30 menit diinduksi dengan larutan sukrosa $5625 \mathrm{mg} / \mathrm{kgBB}$ naik menjadi $189,98 \mathrm{mg} / \mathrm{dL}$ atau meningkat $58,88 \%$. Hasil ini sejalan dengan penelitian Kanon (2012), bahwa tikus yang diinduksi dengan larutan sukrosa $5625 \mathrm{mg} / \mathrm{kgBB}$ dapat menyebabkan hiperglikemia, dengan kenaikan kadar glukosa darah $>50 \%$. Terjadinya hiperglikemia atau peningkatan kadar glukosa darah melebihi kadar normalnya (melebihi $105 \mathrm{mg} / \mathrm{dL}$ ) disebabkan oleh penyerapan glukosa yang dikonsumsi berlebih oleh tubuh sehingga masuk ke dalam darah. Konsumsi glukosa berlebih menyebabkan sel $\beta$ tidak dapat bekerja optimal menghasilkan hormon insulin sebagai respon dari tingginya kadar glukosa darah (Kondoy et al., 2013).

Pada penelitian ini digunakan sukrosa untuk membuat hiperglikemik, diketahui dengan pemberian sukrosa memberikan efek yang cukup cepat menaikkan kadar glukosa darah tikus (Kondoy et al., 2013) dan sebagai kontrol positif (pembanding) digunakan Glibenklamid sebagai obat pembanding karena dapat meningkatkan sekresi insulin 
(Guyton and Hall, 1997). Glibenklamid hanya efektif pada diabetes mellitus tipe II yang keadaan diabetesnya tidak begitu berat dan yang sel betanya masih bekerja cukup baik (Tjay dan Rahardja dalam Pasaribu et al., 2012).
Prosentase perubahan kadar glukosa darah tikus hiperglikemia pada pemberian sediaan ekstrak etanol tumbuhan suruhan dengan dosis berbeda pada 30,60 dan 120 menit setelah pemberian sediaan per oral sampai dapat dilihat pada Gambar 1.

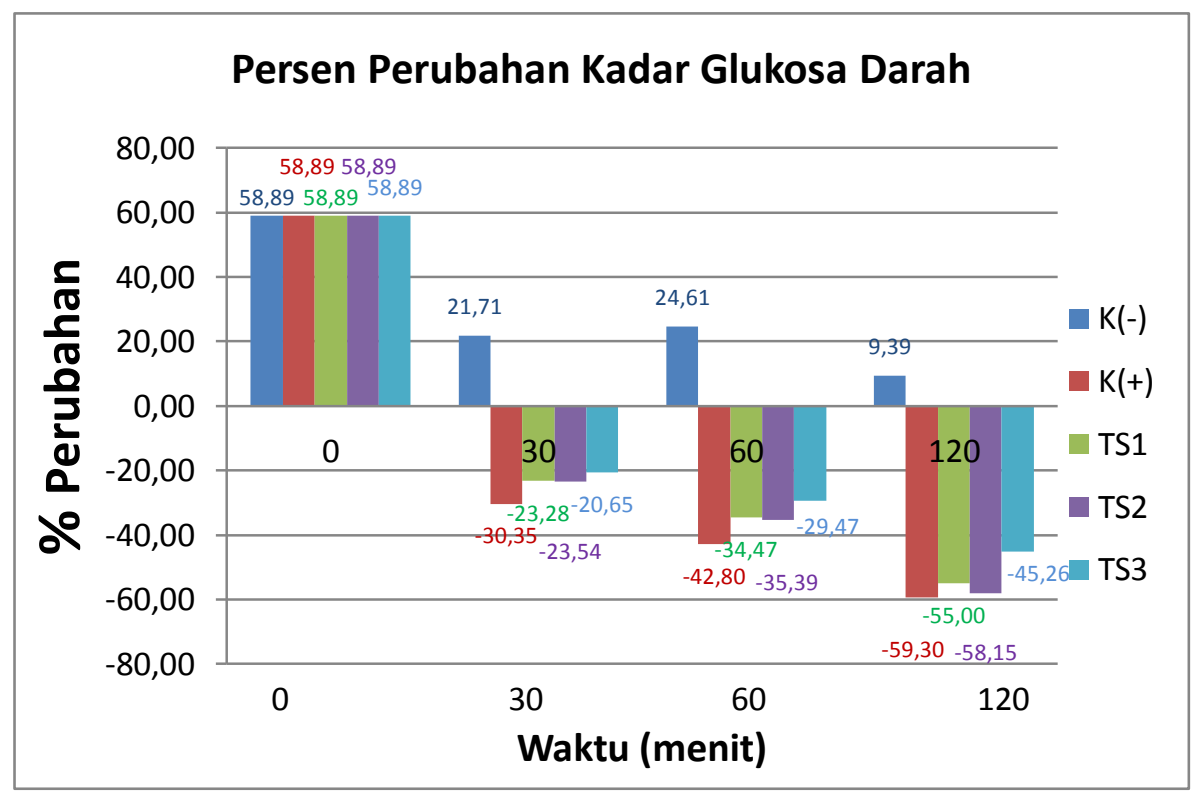

Catatan : Tanda (-) pada angka menunjukkan persen penurunan kadar glukosa darah Keterangan :

K(-) : Kelompok Perlakuan Kontrol Negatif diberi CMC 0,5\%

$\mathrm{K}(+) \quad$ : Kelompok Perlakuan Kontrol Positif diberi Glibenklamid dosis $0,45 \mathrm{mg} / \mathrm{kgBB}$

$\mathrm{TS}_{1} \quad$ : Kelompok Perlakuan Ekstrak Tumbuhan Suruhan dengan dosis $20 \mathrm{mg} / \mathrm{kgBB}$

$\mathrm{TS}_{2} \quad$ : Kelompok Perlakuan Ekstrak Tumbuhan Suruhan dengan dosis $40 \mathrm{mg} / \mathrm{kgBB}$

$\mathrm{TS}_{3} \quad$ : Kelompok Perlakuan Ekstrak Tumbuhan Suruhan dengan dosis $80 \mathrm{mg} / \mathrm{kgBB}$

Gambar 1. Prosentase Perubahan Kadar Glukosa Darah Tikus Wistar yang Hiperglikemia

Hasil pengukuran kadar glukosa darah tikus menunjukan bahwa pemberian ekstrak etanol tumbuhan suruhan (Peperomia pellucida [L.] Kunth) per oral dengan dosis 20; 40; $80 \mathrm{mg} / \mathrm{kgBB}$ memberikan efek antihiperglikmik (penurunan kadar glukosa darah) pada semua dosis. Hasil Penelitian sebelumnya juga menunjukkan fraksi etil asetat tumbuhan suruhan memiliki aktifitas hipoglikemik dengan prosentase penurunan 53,44\% (Kusumawarni, 2012).

Berdasarkan Gambar 1, terjadi penurunan adanya kadar glukosa darah tikus dari masing-masing kelompok setelah 30 menit pemberian sediaan uji dan terus mengalami penurunan kadar glukosa darah sampai 120 menit pemberian sediaan uji, kecuali pada kelompok kontrol negatif.
Sebelumnya semua tikus mengalami kenaikan kadar glukosa darah mencapai kadar tertinggi pada 30 menit setelah pemberian sukrosa sebesar $58,88 \%$. Kecuali pada kelompok perlakuan negatif, perlakuan yang diinduksi CMC 0,5\%, kenaikan kadar glukosa darahnya lebih tinggi dibandingkan dengan kelompok perlakuan ekstrak tumbuhan suruhan dan Glibenklamid. Terlihat bahwa kadar glukosa darah pada kelompok kontrol negatif terus naik dan mencapai kadar tertinggi pada menit ke-60 setelah pemberian CMC 0,5\% menit ke-90 setelah diinduksi sukrosa sebesar $24,61 \%$. Ini menunjukkan bahwa pemberian suspense CMC 0,5\% tidak menunjukan pengaruh pada kadar glukosa darah tikus. CMC diduga tidak berpengaruh terhadap perubahan kadar 
glukosa darah karena tidak dicernakan dan tidak diabsorpsi (Delgado, 1982).

Kelompok perlakuan kontrol positif yang diberikan Glibenklamid terjadi penurunan saat 30 menit setelah pemberian obat sebesar $30,34 \%$ dan terus menurun sampai menit ke-120 setelah pemberian obat sebesar 59,29\%. Penurunan hampir mencapai kadar glukosa darah normal. Ganiswara dan Hardjasaputra et al. dalam Fahri et al. (2005), menyatakan bahwa Glibenklamid merupakan salah satu obat turunan sulfonilurea dengan potensi penurunan kadar glukosa darah lebih tinggi dibanding sulfonilurea lain.

Begitu juga dengan kelompok perlakuan ekstrak tumbuhan suruhan, berdasarkan Gambar 1 terjadi penurunan kadar glukosa darah setelah 30 menit pemberian ekstrak tumbuhan suruhan dan terus mengalami penurunan kadar glukosa darah sampai menit ke-120 setelah pemberian ekstrak tumbuhan suruhan. Ini menunjukan ekstrak tumbuhan suruhan memiliki efek hipoglikemik pada tikus jantan Wistar. Hal ini diduga kenaikan kadar glukosa darah tikus ditahan dengan adanya pengaruh dari pemberian ekstrak tumbuhan suruhan dan glibenklamid, sehingga efek dari penurunan kadar glukosa darah lebih cepat dibandingkan dengan CMC 0,5\%. Pada Gambar 3 dapat dilihat bahwa hasil pengujian kadar glukosa darah dengan dosis $40 \mathrm{mg} / \mathrm{kgBB}$ memberikan penurunan kadar glukosa darah yang signifikan dan berbeda nyata (beda) dibandingkan kelompok perlakuan kontrol negatif yang diinduksi CMC $0,5 \%$ dan tidak memberikan perbedaan yang nyata (sama) dengan glibenklamid dosis $0,45 \mathrm{mg} / \mathrm{kgBB}$.

Hasil analisa penurunan kadar glukosa darah menunjukkan bahwa pemberian ekstrak tumbuhan suruhan dosis $40 \mathrm{mg} / \mathrm{kgBB}$ memberikan penurunan kadar glukosa darah yang paling baik dibandingkan dosis $20 \mathrm{mg} / \mathrm{kgBB}$ dan 80 $\mathrm{mg} / \mathrm{kgBB}$. Pada dosis $80 \mathrm{mg} / \mathrm{kgBB}$ justru terjadi penurunan efek.

Ekstrak tumbuhan suruhan pada dosis $40 \mathrm{mg} / \mathrm{kgBB}$ memperlihatkan efek penurunan kadar glukosa darah yang efektif terhadap prosentase penurunan kadar glukosa darah tikus, pada menit ke-30 sebesar 23,54\% dan penurunannya terus meningkat sampai menit ke-120 sebesar
$58,15 \%$ dibandingkan pada ekstrak tumbuhan suruhan $20 \mathrm{mg} / \mathrm{kgBB}$ menit ke-30 sebesar 23,28\% sampai menit ke-120 sebesar $54,99 \%$ dan ekstrak tumbuhan suruhan $80 \mathrm{mg} / \mathrm{kgBB}$ menit ke-30 sebesar $20,65 \%$ sampai menit ke-120 sebesar $45,26 \%$. Hasil analisa penurunan kadar glukosa darah menunjukkan bahwa pemberian ekstrak tumbuhan suruhan dosis $40 \mathrm{mg} / \mathrm{kgBB}$ memberikan penurunan kadar glukosa darah yang paling baik (signifikan) dibandingkan dosis $20 \mathrm{mg} / \mathrm{kgBB}$ dan 80 $\mathrm{mg} / \mathrm{kgBB}$ dan pada dosis $80 \mathrm{mg} / \mathrm{kgBB}$ justru terjadi penurunan efek. Hal ini disebabkan pada dosis ini kemampuan tubuh untuk menyerap obat tersebut sudah maksimal, sedangkan pada dosis yang lebih kecil yaitu $20 \mathrm{mg} / \mathrm{kgBB}$ belum maksimal tetapi dan pada dosis yang lebih besar $80 \mathrm{mg} / \mathrm{kgBB}$ efek penurunan kadar glukosa darahnya justru menurun. Hal ini dikarenakan kemampuan maksimal penurunan kadar glukosa darah sudah bekerja pada dosis 40 $\mathrm{mg} / \mathrm{kgBB}$, sehingga ketika dosis ditambah tidak akan terlalu banyak pengaruhnya pada tubuh, bahkan bisa menjadi toksik akibat pemberian dosis yang berlebih (Saleh et al., 2012).

Peningkatan dosis obat seharusnya meningkatkan respon yang sebanding dengan dosis yang ditingkatkan, namun dengan meningkatnya dosis peningkatan respon pada penelitian ini justru menurun, karena sudah mencapai dosis yang tidak dapat meningkatkan respon lagi. Hal ini sering terjadi pada obat bahan alam, karena komponen senyawa yang dikandungnya tidak tunggal melainkan terdiri dari berbagai macam senyawa kimia, dimana komponenkomponen tersebut saling bekerjasama untuk menimbulkan efek, sehingga terjadi interaksi merugikan yang menyebabkan penurunan efek. Hasil analisis menunjukkan bahwa peningkatan dosis ekstrak tumbuhan suruhan pada dosis $80 \mathrm{mg} / \mathrm{kgBB}$ tidak diikuti dengan peningkatan aktivitas antihiperglikemik. Hal ini karena telah jenuhnya reseptor yang berikatan dan terjadinya interaksi dengan senyawa kimia yang terkandung di dalam tumbuhan suruhan. Jika reseptor telah jenuh, maka peningkatan dosis tidak bisa mencapai efek maksimumnya (Pasaribu et al., 2012).

Kemampuan ekstrak tumbuhan suruhan dalam menurunkan kadar glukosa darah tikus, diduga disebabkan oleh senyawa 
flavonoid yang terdapat dalam ekstrak tumbuhan tersebut. Nwokocha et al. (2012) melaporkan bahwa tumbuhan suruhan mengandung senyawa flavonoid. Senyawa flavonoid merupakan senyawa antioksidan dan diduga mengembalikan sensitifitas reseptor insulin pada sel, kondisi tersebut menyebabkan penurunan kadar glukosa darah tikus (Saleh et al., 2012). Ganugapati et al. (2012) melaporkan bahwa flavonoid yang diisolasi dari pisang memiliki potensi untuk mengaktifkan reseptor insulin pada sel dan menjadi pilihan alternatif untuk pengobatan pasien diabetes melitus tipe II dengan resistensi insulin.

Selain itu, dalam sebuah studi klinis, (Sattanathan et al., 2011) melaporkan bahwa pemberian tumbuhan yang mengandung flavonoid secara rutin, dapat menjadi obat hipoglikemik oral karena dapat mengontrol penderita diabetes melitus tipe II.

Berdasarkan analisis statistik diperoleh signifikansi, yang berarti ada perbedaan yang bermakna antar perlakuan. Dari uji statistik didapatkan perbedaan bermakna antara kelompok perlakuan kontrol negatif (K-), kelompok perlakuan kontrol positif $(\mathrm{K}+)$ dan kelompok perlakuan ekstrak etanol tumbuhan suruhan (TS). Kelompok perlakuan ekstrak etanol tumbuhan suruhan dosis $40 \mathrm{mg} / \mathrm{kgBB}$ pada menit ke-120 menunjukkan dosis yang efektif diantara kelompok perlakuan ekstrak etanol tumbuhan suruhan dosis 20 dan 80 $\mathrm{mg} / \mathrm{kgBB}$. Hal ini menunjukkan bahwa ekstrak etanol tumbuhan suruhan dosis 40 $\mathrm{mg} / \mathrm{kgBB}$ pada menit ke-120 memiliki aktifitas dalam menurunkan kadar glukosa darah yang signifikan pada tikus jantan Wistar sedangkan CMC 0,5\% tidak.

\section{KESIMPULAN DAN SARAN}

\subsection{Kesimpulan}

Penelitian ini menyimpulkan bahwa dosis optimum dari ekstrak etanol tumbuhan suruhan (Peperomia pellucida [L.] Kunth) yang efektif dalam menurunkan kadar glukosa darah tikus yang hiperglikemia akibat diinduksi sukrosa adalah $40 \mathrm{mg} / \mathrm{kgBB}$ pada menit ke-120.

\subsection{Saran}

Untuk penelitian selanjutnya perlu dilakukan isolasi dan karakterisasi terhadap senyawa aktif antihiperglikemik pada ekstrak tumbuhan suruhan.

\section{DAFTAR PUSTAKA}

Delgado, J.N. 1982. Karbohidrat, Buku Teks Wilson dan Gisvold.Kimia Farmasi dan Medisinal Organik I.Terjemahan Fattah, A.M. IKIP Semarang Press, Semarang.

Fahri, C., Sutarno., S. Listyawati. 2005. Kadar Glukosa dan Kolesterol Total Darah Tikus Putih (Rattus norvegicus L.)Hiperglikemik setelah Pemberian Ekstrak MetanolAkar Meniran (Phyllanthus niruri L.).Biofarmasi.3: 1-6.

Ganugapati, J., A. Baldwa., and S. Lalani. 2012. Molecular Docking Studies of Banana Flower Flavonoids as Insulin Receptor Tyrosine Kinase Activators as a Cure for Diabetes Mellitus. Bioinformation8: 216-220.

Guyton, A.C., and J.E. Hall.Buku Ajar Fisiologi Kedokteran.Edisi ke-9. Terjemahan Setiawan. EGC, Jakarta.

Helrich, K. 1999. Official Methods of Analysis of Association of Official Analitical Chemists. Edisi ke15.Chapter 44.1.03, Association of Official Analytical Chemist [AOAC]. United States of America.

Hussain, S.A., and B.H. Marouf. 2013. Flavonoids as Alternatives in Treatment of Type 2 Diabetes Mellitus. Academia Journal of Medicinal Plants.1: 031-036.

Kanon, M.Q., Fatimawali., dan W. Bodhi. 2012. Uji Efektivitas Ekstrak Kulit Buah Salak (Salacca zalacca (Gaertn.) Voss) terhadap Penurunan Kadar Gula Darah Tikus Putih Jantan Galur Wistar (Rattus norvegicus L.) yang Diinduksi Sukrosa.Pharmacon.1: 52-58. 
Khan, A., M. Rahman., and S. Islam. 2008. Neuropharmacological Effects of Peperomia pellucida Leaves in Mice. DARU.16:35-40.

Kondoy, S., A.Wullur., dan W. Bodhi. 2013. Potensi Ekstrak Etanol Daun Kayu Manis (Cinnamomum burmanii) terhadap Penurunan Kadar Glukosa Darahdari Tikus Putih Jantan (Rattus Norvegicus) yang DiinduksiSukrosa .Pharmacon.2: 96-99.

Kusumawarni, P., Supriyatna., dan Y. Susilawati.Aktivitas Antidiabetes Fraksi Etil Asetat dari Herba Sasaladaan (Peperomia pellucida (L.)Kunth.)dengan Metode Induksi Aloksan. Students E-Journals.1:1.

Mun'im, A., Azizahwati., dan A.F. Firmani. 2011. Pengaruh Pemberian Infusa Daun Sirih Merah (Piper cf. fragile Benth) secara Topikal terhadap Penyembuhan Luka pada Tikus Putih Diabet.Jurnal Bahan Alam Indonesia.7:234-238.

Nwokocha, C.R., D.U. Owu., K. Kinlocke., J. Murray., R. Delgoda., K. Thaxter., G. McCalla., and L. Young. 2012. Possible Mechanism of Action of the Hypotensive Effect of Peperomiapellucida and Interactions between Human Cytochrome P450 Enzymes. Medicinal and Aromatic Plants.1:1-5.

Pasaribu, F., P. Sitorus., dan S. Bahri. 2012. Uji Ekstrak Etanol Kulit Buah Manggis (Garcinia mangostana L.) Terhadap Penurunan Kadar Glukosa Darah. Journal of Pharmaceutics and Pharmacology.1:1-8.

Saleh, C., S. Sitorus., dan R. Nursanti.2012. Uji Hipoglikemik Ekstrak Etanol Umbi Anredera cordifolia [Ten.]Steenis. Mulawarman Scientifie. 11: 95-99.

Samuelsson, G. 1999. Drug of Natural Origin, a Text Book of Pharmacognosy. Stockholm, Swedish Pharmaceutical Press.
Sattanathan, S., C.K. Dhanapal., R. Umarani., and R. Manavalan. 2011. Beneficial Health Effects of Rutin Supplementation in Patients with Diabetes Mellitus. J. Appl. Pharm. Sci. 1: 227-231.

Soegondo, S., P. Soewondo., dan I. Subekti.2009. Penataklaksanaan Diabetes Mellitus Terpadu.Edisi ke2.BalaiPenerbit FKUI, Jakarta.

Taguchi, Y. 1985. Experimental Animals.Clea Japan, Inc. Tokyo.

Wijaya, S., dan S.W. Monica.2004. Uji Efek Antiinflamasi Ekstrak Herba Suruhan (Peperomia pellucida L. Kunth) pada Tikus Putih Jantan.Berk.Penel.Hayati. $\quad$ 9:115118.

Xu, S., N. Li., M.M. Ning., C.H. Zhou., Q.R. Yang., and M.W. Wang. 2005. Bioactive Compounds from Peperomia pellucid. American Chemical Society and American Society of Pharmacognosy.10:1. 